Saudi Journal of Biomedical Research

Abbreviated Key Title: Saudi J Biomed Res ISSN 2518-3214 (Print) |ISSN 2518-3222 (Online)

\title{
Assessment of Zinc and Copper among Patients with Abnormal Semen: Analysis
}

\author{
Khansa T. Salim ${ }^{1,2^{*}}$, Afra O. Ali ${ }^{1}$, Rabab A. Babiker ${ }^{1}$, Mohamed A. Gafoor ${ }^{2}$, Mohammed Omer Hussien ${ }^{2}$, Maha \\ Alameen ${ }^{2}$, Mosab Nouraldein Mohammed Hamad ${ }^{2}$, Abdelkarim A. Abdrabo ${ }^{1}$ \\ ${ }^{1}$ Department of clinical chemistry, Faculty of Medical Laboratory Sciences, Sudan International University, Khartoum, Sudan \\ ${ }^{2}$ Banoon Fertility Center, Khartoum, Sudan
}

\author{
DOI: $10.36348 /$ sjbr.2019.v04i12.002 \\ *Corresponding author: Khansa T. Salim
}

| Received: 05.12.2019| Accepted: 16.12.2019| Published: 18.12.2019

\section{Abstract}

Background: Zinc is an essential mineral that is found in almost every cell in the body. It is a key factor in making many parts of the reproductive system work properly. Copper play important role in male fertility it is essential element for the production of male gametes, substantial amounts of cu can also be found in liquids associated with sperm in the epididymis and prostate, also effect the integral androgen distribution in terms of fertility on the line hypothalamicpituitary-testis. Objective: To access the level of zinc and copper in serum among Sudanese male with abnormal semen analysis. Materials and Methods: This is a case control study carried out from Banoon fertility center in period from March to May 2018. We quantified the levels of $\mathrm{Zn}$ and $\mathrm{Cu}$ in serum samples from 50 patients of infertility and 50 healthy control people. These elements were determined using atomic absorption spectrophotometer. Results: $\mathrm{Zn}$ and $\mathrm{Cu}$ were significantly lower in infertile men patients, $(0.269 \pm 0.093 \mathrm{mg} / \mathrm{l})(0.223 \pm 0.084 \mathrm{mg} / \mathrm{l})$ when compared with control group, $(0.579 \pm 0.224 \mathrm{mg} / \mathrm{l})(0.821 \pm 0.179 \mathrm{mg} / \mathrm{l})$, with $\mathrm{P}$ value $(0.000)$ respectively. $)$. Conclusion: There is a defect in levels of $\mathrm{Zn}$ and $\mathrm{Cu}$ in infertile men patients. The estimation of these trace elements could be a useful complementary in diagnosis and monitoring for infertility.

Keywords: Zinc, copper, semen, abnormalities.

Copyright @ 2019: This is an open-access article distributed under the terms of the Creative Commons Attribution license which permits unrestricted use, distribution, and reproduction in any medium for non-commercial use (NonCommercial, or CC-BY-NC) provided the original author and source are credited.

\section{INTRODUCTION}

Infertility is defined as the lack of ability to conceive within one year of unprotected intercourse with the same partner [1]. It is estimated that nearly $8-$ $12 \%$ of couples are infertile, and approximately 30$40 \%$ of infertility cases are caused by male factors [2]. Several risk factors are involved in the pathogenesis of infertility, some of which include alterations in spermatogenesis due to testicular cancer, aplasia of the germinal cells, varicocele, defects in the transport of sperm, or environmental factors as well as congenital anomalies, infectious diseases, bilateral sperm ducts, alterations in the characteristics of semen such as a decrease in sperm motility and sperm count, the presence of anti sperm antibodies (ASAs), and nutritional deficiency of trace elements such as selenium and zinc (Zn) [3-6]. The World Health Organization (WHO) estimates that one-third of the world's population is deficient in zinc. Zinc and citrate are excreted from the prostate gland as a lowmolecular-weight complex; thus, it is estimated that the zinc levels in seminal plasma typically represent prostatic secretary function. After ejaculation, half of the quantity of this complex is redistributed and linked to medium- and high-molecular-weight compounds generated from the seminal vesicles [7]. The decrease in the seminal plasma zinc concentration may result in inadequate intake, reduced absorption, increased losses, or increased demand. Additionally, the commonest worldwide cause is inadequate intake as a result of a diet low in $\mathrm{Zn}$ or rich in phytate. Additionally, increased urinary losses can occur under conditions associated with muscle catabolism, such as sepsis, or iatrogenic from the prolonged use of drugs [8,9]. Furthermore, some studies have reported that a sharp decrease in zinc in the prostatic fluid must result in a decreased zinc concentration in seminal plasma [10].

\section{MATERIALS AND METHODS \\ Study Design and Study Area}

Cross Sectional - Case control study conducted from March to May 2018 in Banoon fertility center. 


\section{Study Population}

One hundred (100) subjects were recruited for this study divided into two groups, 50subjects as study group and 50 as control group.

\section{Ethical Considerations}

Permission of study obtained from local scientific committee of Sudan international university in the study area, all participants were informed verbally by the aims of the study.

\section{Sampling Collection and Processing}

Following aseptic techniques, $3.0 \mathrm{ml}$ of venous blood collected from the group of the study. Serum obtained by centrifugation and then kept at 20c until tested. The samples diluted with 1:5 of deionized water for zinc, and with an equal volume for copper, then atomic absorption spectrophotometer used to determine its levels.

\section{STATISTICAL ANALYSIS}

The data was analyzed using SPSS version 21. The results expressed as mean Standard deviation and percentage. Independent T-test obtained to compare the study parameters between the case and control. Use ANOVA test to compare $\mathrm{b} / \mathrm{w} \mathrm{Zn}$ and $\mathrm{cu}$ value with seminal analysis.

\section{RESULTS}

The study includes 100 subjects (50 as case and 50 as control group) the range age of patients from 25-62 years and their mean age 41.9 9.4.and ranges of control age $21-59$ years and their mean age $(40.9+8.7)$, (Table-1). The result showed significant decrease in serum zinc and copper in seminal fluid (oligo, terato, astheno, azoospermia) (Figure-1). The mean zinc level was significant decreased among infertile men $(0269 \pm$ $0.093)$ when compared to control group $(0.579 \pm 0.224)$ p.value (0.00). And the mean copper level was significant decreased among infertile men (0.223 \pm $0.084)$ when compared to control group $(0.821 \pm 0.179)$ p.value $(0.00)$, (Table-2) there were no significant difference in $\mathrm{Zn}$ level in respond to different type of seminal analysis p.value (0.758), and no significant difference in cu level in respond to different type of seminal analysis p.value(0.427), (Table-3). There were no association between the $\mathrm{Zn}$ and $\mathrm{Cu}$ with Age $(\mathrm{R}=-$ 0.080, $\mathrm{P}=0.579)(\mathrm{R}=0.075, \mathrm{P}=0.606)$, (Figure-4).

Table-1: Shows the age of the study groups

\begin{tabular}{|l|l|l|l|l|}
\hline Variables & Group & Minimum & Maximum & Mean \pm SD \\
\hline Age (Years) & Case & 25.0 & 62.0 & $41.0 \pm 9.4$ \\
\cline { 2 - 5 } & Control & 21.0 & 59.0 & $40.9 \pm 8.7$ \\
\hline
\end{tabular}

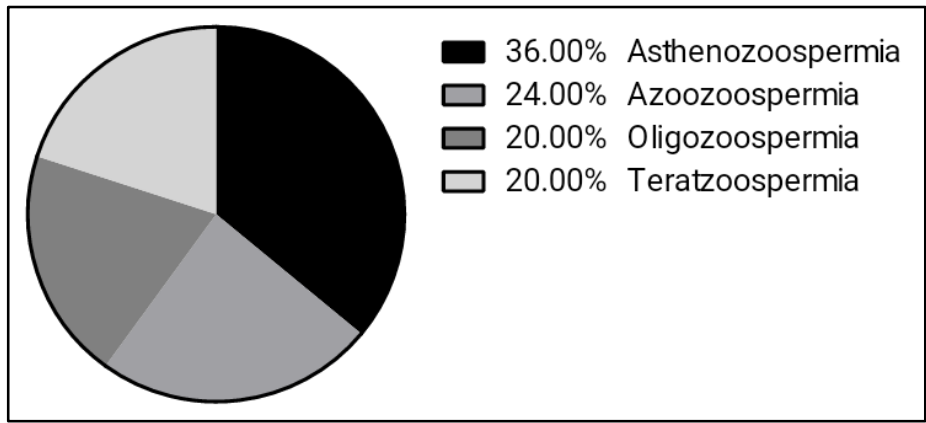

Fig-1: Distributions of patients according to semen result .out of 50 patients, 36 were asthenozoospermia

Table-2: Men comparison of study parameter

\begin{tabular}{|l|l|l|l|}
\hline Parameters & Case (Mean \pm SD) & Control (Mean \pm SD) & $P$-value \\
\hline Zinc $(\mathbf{m g} / \mathbf{d I})$ & $0.269 \pm 0.093$ & $0.579 \pm 0.224$ & 0.000 \\
\hline Copper $(\mathbf{m g} / \mathbf{d I})$ & $0.223 \pm 0.084$ & $0.821 \pm 0.179$ & 0.000 \\
\hline
\end{tabular}

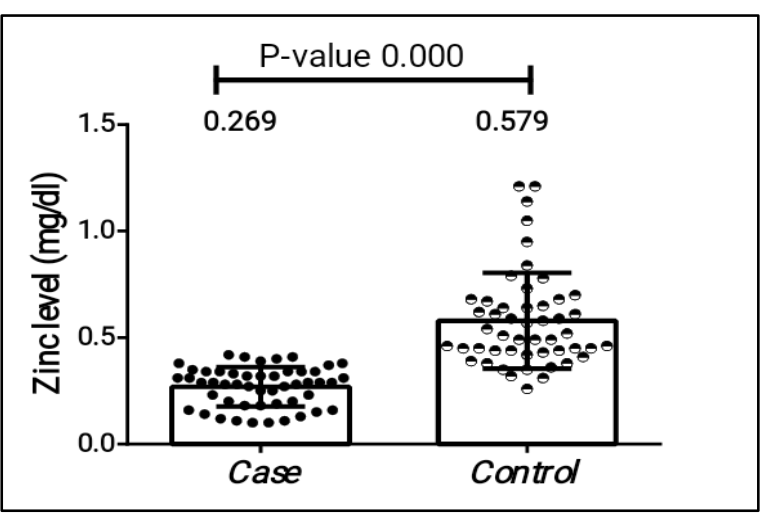

Fig-2: Mean concentration of zinc in case and control

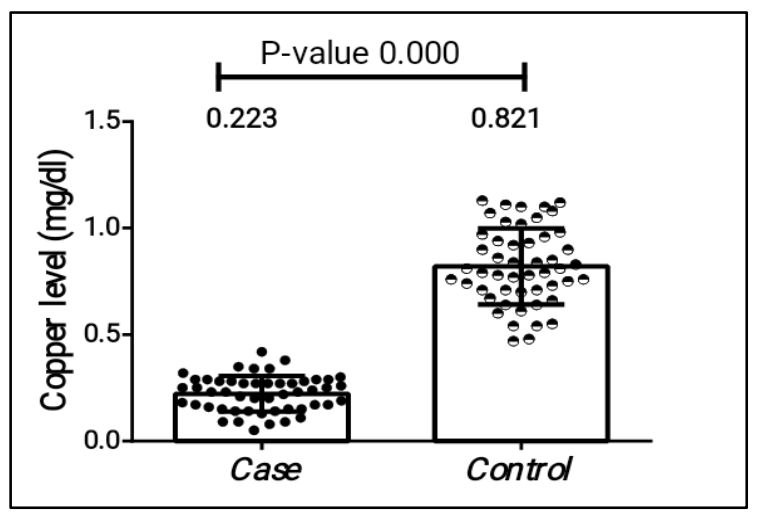

Fig-3: Mean concentration of copper in case and control 
Table-3: Mean of serum Zinc and Copper in different types of abnormal semen fluid analysis

\begin{tabular}{|c|c|c|}
\hline Parameters & Mean \pm SD & P-value \\
\hline \multicolumn{3}{|l|}{ Zinc } \\
\hline Azoospermia & $0.29 \pm 0.08$ & \multirow{4}{*}{0.758} \\
\hline Asthenozoospermia & $0.25 \pm 0.09$ & \\
\hline Oligozoospermia & $0.27 \pm 0.09$ & \\
\hline Teratzoospermia & $0.26 \pm 0.10$ & \\
\hline \multicolumn{3}{|l|}{ Copper } \\
\hline Azoozoospermia & $0.24 \pm 0.07$ & \multirow{4}{*}{0.427} \\
\hline Asthenozoospermia & $0.23 \pm 0.08$ & \\
\hline Oligozoospermia & $0.23 \pm 0.12$ & \\
\hline Teratzoospermia & $0.18 \pm 0.06$ & \\
\hline
\end{tabular}
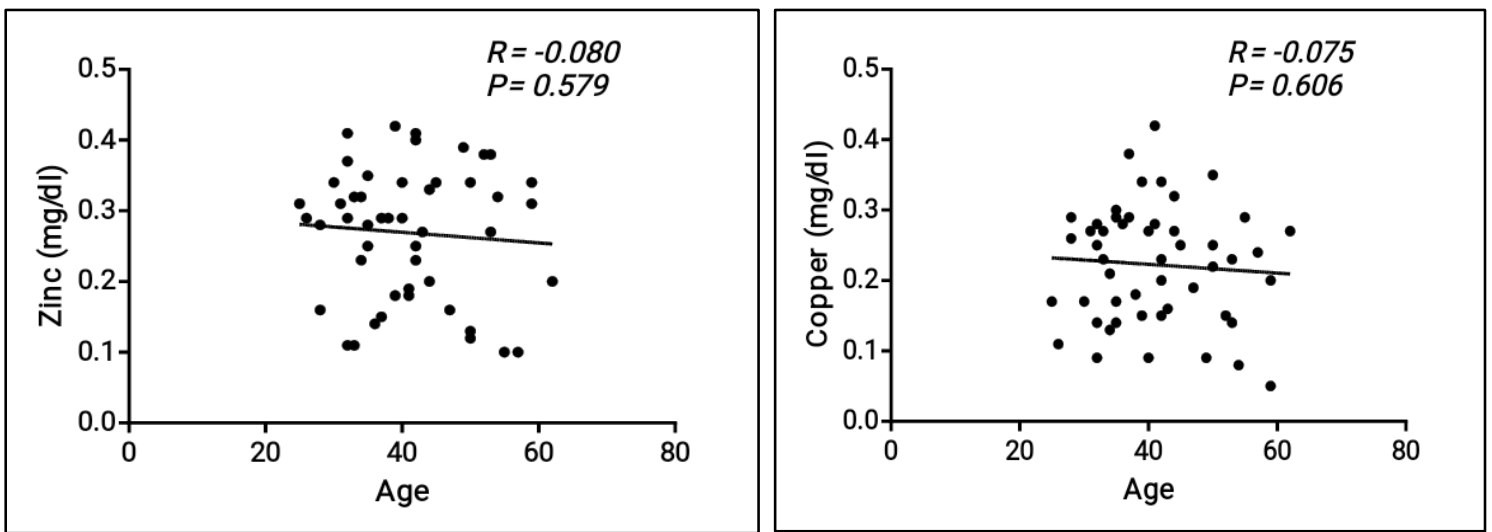

Fig-4: Correlation between zinc and copper with age

\section{DISCUSSION}

The role of trace elements in infertility is of great interest because many of them are co-factors in reproductive system involving epididymis and prostate [11]. Levels of $\mathrm{Zn}$ and $\mathrm{Cu}$ were low in infertile male patient compared with normal group $\mathrm{P}$-value (0.000), this finding is agreement with a study done in national university of Singapore [12], also in accordance with other study conducted in Sudan [13]. The reduction in serum $\mathrm{Zn}$ levels may be related to multiple causes and consequences depending on the gender, sexual history, life style and cultural background [14]. A previous study reported that significant difference in serum and seminal zinc level in normospermic, oligospermic $(\mathrm{p}<0.05)$ and azoospermic $(\mathrm{p}<0.005)[15]$.

Other study shows the different result. Zinc $(\mathrm{Zn})$ and copper $(\mathrm{Cu})$ concentrations in sera and seminal plasma of 60 infertile males (40 oligozoospermic and 20 azoospermic) and 40 males with evidence of fertility (normozoospermic; controls) were estimated using atomic absorption spectrophotometry. The mean serum concentration of zinc was significantly $(p<0.01)$ higher in oligozoospermic males when compared to azoospermic subjects and controls. The ratios of serum $\mathrm{Zn}$ to seminal plasma $\mathrm{Zn}$ were 1:1, 1:3 or 1:4 in oligozoospermic, normozoospermic or azoospermic subjects, respectively. While the mean $\mathrm{Cu}$ concentration was significantly higher in serum than seminal plasma in all groups, the $\mathrm{Zn}$ concentration was significantly $(\mathrm{p}<0.05)$ higher in seminal plasma than serum. $\mathrm{Cu} / \mathrm{Zn}$ ratio in seminal plasma was significantly $(\mathrm{p}<0.01)$ higher in controls compared with other groups [16].

\section{CONCLUSION}

On this basis of the finding of the present study, zinc and copper considered a useful tool in addition to other parameters in assessing male infertility.

\section{REFERENCES}

1. Abarikwu, S. O. (2013). Causes and risk factors for male-factor infertility in Nigeria: a review. African Journal of Reproductive Health, 17(4):150-166.

2. Cardona-Maya, W., Velilla, P., Montoya, C. J., Cadavid, Á., \& Rugeles, M. T. (2009). Presence of HIV-1 DNA in spermatozoa from HIV-positive patients: changes in the semen parameters. Current HIV research, 7(4), 418-424.

3. Cardona-Maya, W., Velilla, P. A., Montoya, C. J., Cadavid, Á., \& Rugeles, M. T. (2011). In vitro human immunodeficiency virus and sperm cell interaction mediated by the mannose receptor. Journal of reproductive immunology, 92(1-2), 1-7.

4. Mahdi, B. M., Salih, W. H., Caitano, A. E., Kadhum, B. M., \& Ibrahim, D. S. (2011). Frequency of antisperm antibodies in infertile women. Journal of reproduction \& infertility, 12(4), 261. 
5. Wong, W. Y., Thomas, C. M., Merkus, J. M., Zielhuis, G. A., \& Steegers-Theunissen, R. P. (2000). Male factor subfertility: possible causes and the impact of nutritional factors. Fertility and sterility, 73(3), 435-442.

6. Mandal, A., \& Bhattacharyya, A. K. (1990). Biochemical composition of washed human seminal coagulum in comparison to sperm-free semen from the same donors. Reproduction, $88(1)$, 113-118.

7. Foresta, C., Garolla, A., Cosci, I., Menegazzo, M., Ferigo, M., Gandin, V., \& De Toni, L. (2014). Role of zinc trafficking in male fertility: from germ to sperm. Human reproduction, 29(6), 1134-1145.

8. Hunt, C. D., Johnson, P. E., Herbel, J., \& Mullen, L. K. (1992). Effects of dietary zinc depletion on seminal volume and zinc loss, serum testosterone concentrations, and sperm morphology in young men. The American journal of clinical nutrition, 56(1), 148-157.

9. Vallee, B. L. (1959). The biochemistry, physiology and pharmacology of zinc. Physiol Rev, 39:443458.

10. Wu, X., Tang, J., \& Xie, M. (2015). Serum and hair zinc levels in breast cancer: a metaanalysis. Scientific reports, 5, 12249.

11. Ogorek, M., Pierzchała, O., Daszkiewicz, R., \& Lenartowicz, M. (2017). Role of copper in the process of spermatogenesis. Postepy higieny $i$ medycyny doswiadczalnej (Online), 71, 663-683.

12. Chia, S. E., Ong, C. N., Chua, L. H., Ho, L. M., \& Tay, S. K. (2000). Comparison of zinc concentrations in blood and seminal plasma and the various sperm parameters between fertile and infertile men. Journal of andrology, 21(1), 53-57.

13. Altaher, Y. M., \& Abdrabo, A. A. (2015). Levels of Zinc and Copper in seminal plasma of Sudanese infertile males. British Journal of Medicine and Medical Research, 5(4), 533.

14. Gurunath, S., Pandian, Z., Anderson, R. A., \& Bhattacharya, S. (2011). Defining infertility-a systematic review of prevalence studies. Human reproduction update, $17(5), 575-588$.

15. Ali, H., Ahmed, M., Baig, M., \& Ali, M. (2007). Relationship of zinc concentrations in blood and seminal plasma with various semen parameters in infertile subjects. Pakistan Journal of Medical Sciences, 23(1), 111-114.

16. Stanwell-Smith, R., Thompson, S. G., Haines, A. P., Ward, R. J., Cashmore, G., Stedronska, J., \& Hendry, W. F. (1983). A comparative study of zinc, copper, cadmium, and lead levels in fertile and infertile men. Fertility and sterility, 40(5), 670677. 